\title{
Ameliorative effects of curcumin and caffeic acid against short term exposure of waterpipe tobacco smoking on lung, heart and kidney in mice
}

\author{
Alia Khwaldeh ${ }^{1}$, Ali Abu Siyam ${ }^{1}$, Ahmed Alzbeede ${ }^{2,3}$, Mohammad Farajallah $^{2}$, Ziad Shraideh ${ }^{2}$, \\ Darwish Badran ${ }^{4}$ \\ ${ }^{1}$ Department of Medical Laboratory Sciences, Faculty of Pharmacy, Jadara University, Irbid, ${ }^{2}$ Department of Biological Sciences, School of Science, The \\ University of Jordan, Amman, Jordan, ${ }^{3}$ Department of Medical Laboratory Science, College of Science, Komar University of Science and Technology, \\ Sulaymaniyah, Iraq, ${ }^{4}$ Department of Anatomy and Histology, School of Medicine, The University of Jordan, Amman, Jordan
}

\begin{abstract}
This study aims to evaluate the chemopreventive activity of two antioxidants (curcumin [CUM] and caffeic acid $[\mathrm{CAF}]$ ), focusing on how these antioxidants could reduce cytotoxicity induced by short term secondhand exposure of waterpipe tobacco smoking. Forty-eight adult male BALB/c albino mice were equally divided into four groups. Antioxidants were delivered intraperitoneally, and the exposure to waterpipe smoking (WPS) was performed using a smoking machine. This experiment lasts for 14 consecutive days. Serum were collected from mice before dissection to quantify the activity of some liver enzymes, kidney function tests and proinflammatory cytokines. Lung, heart, and kidney were isolated and processed for light microscopy technique. Parallel treatment of CUM or CAF along with exposure to WPS showed less inflammation, less vacuolized, and more inflated alveoli, less deteriorations in cortex part of kidney, and less disintegration of cardiac myofibers in comparison to waterpipe only. Besides, CUM and CAF significantly reduced the activity of aspartate aminotransferase and proinflammatory cytokines. CUM and CAF were found to have anti-inflammatory and ameliorative effects against the cytotoxicity induced by exposure to waterpipe tobacco smoking, and CUM showed better chemopreventive activity than CAF.
\end{abstract}

Key words: Antioxidants, Biochemical parameters, Histopathology, Hookah, Proinflammatory cytokines

Received July 25, 2020; 1st Revised September 12, 2020; 2nd Revised November 7, 2020; Accepted November 9, 2020

\section{Introduction}

Waterpipe and its alternative names like goza, hookah, narghile, and shisha is a single or multi-stemmed instrument

\section{Corresponding author:}

Alia Khwaldeh (iD

Department of Medical Laboratory Sciences, Faculty of Pharmacy, Jadara University, Irbid 21110, Jordan

E-mail: a.khawaldeh@jadara.edu.jo involved in inhalation of tobacco smoking after passing through tap water (Fig. 1A) [1]. World health organization listed waterpipe tobacco smoking as a public health problem that needs fast solutions to regulate its prevalence worldwide by implementing tobacco control measures [2]. The reasons behind that, are due to high concentrations of toxicants present in charcoal and tobacco that have an adverse impact on human health [3]. These toxicants include nicotine, tar, carbon monoxide, volatile organic compounds, heavy metals, polycyclic aromatic hydrocarbons, and heterocyclic aromatic amines (Fig. 2) [4-6]. These compounds were reported to

\section{Copyright (C) 2021. Anatomy \& Cell Biology}

This is an Open Access article distributed under the terms of the Creative Commons Attribution Non-Commercial License (http://creativecommons.org/licenses/by-nc/4.0/) which permits unrestricted non-commercial use, distribution, and reproduction in any medium, provided the original work is properly cited. 

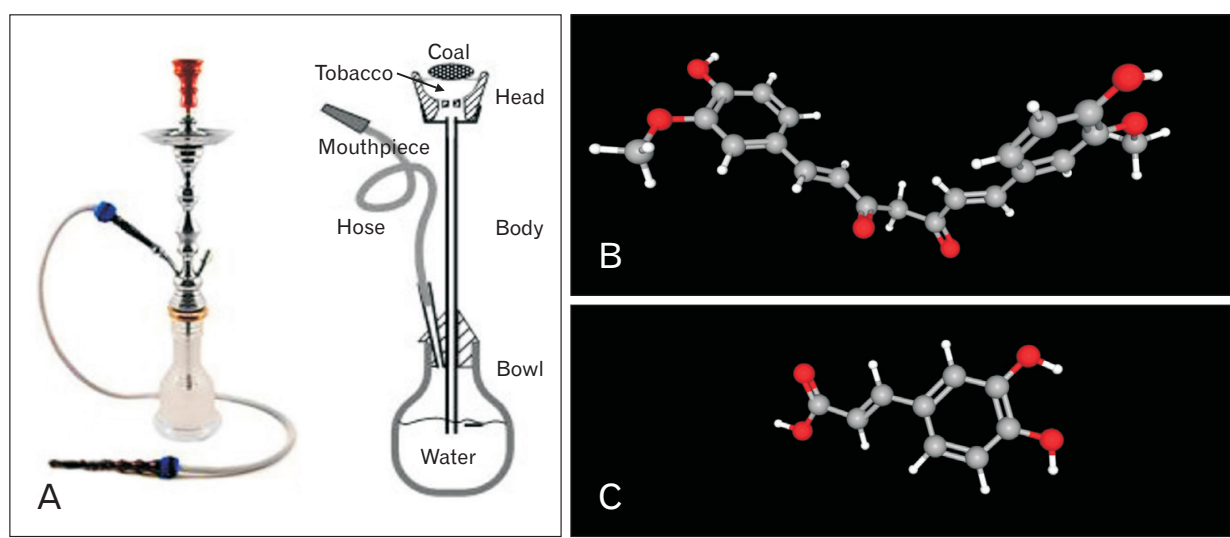

Fig. 1. The main components of this study (WPS, CUM, and CAF); (A) shows a typical waterpipe with a brief illustration of its parts. Chemical structure of CUM (B) and CAF (C) with three-dimensional conformer represented in ball and stick model. CAF, caffeic acid; CUM, curcumin; WPS, waterpipe smoking. Adapted from Bhatnagar et al. Circulation 2019;139:e917-36, according to the Creative Commons license PubChem [1].<smiles>CN1CCC[C@H]1c1cccnc1</smiles>

(Nicotine)

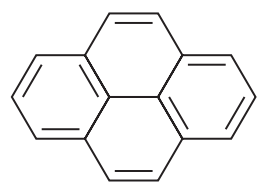

(Pyrene)<smiles>c1ccc2c(c1)cc1ccc3cccc4ccc2c1c34</smiles>

(Benzo[a]pyrene)<smiles>c1ccc2c(c1)c1ccccc1c1ccccc21</smiles>

(Fluoranthene)

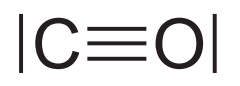

(Carbon monoxide)<smiles>c1ccc2cc3c(ccc4ccccc43)cc2c1</smiles>

(Benzo[a]anthracene)<smiles></smiles>

(Benzo[g,h,i]perylene)

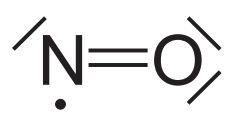

(Nitric oxide)<smiles>c1ccc2c(c1)ccc1c3ccccc3ccc21</smiles>

(Chrysene)<smiles></smiles>

(Indeno[1,2,3-cd]pyrene)<smiles>Oc1ccccc1O</smiles>

(Catechol "Tar")<smiles>Cc1cc(O)ccc1O</smiles>

(Hydroquinone "Tar")<smiles>CC=O</smiles>

(Acetaldehyde)<smiles>CCC=O</smiles>

(Propionaldehyde)<smiles>C=C(C)C=O</smiles>

(Methacrolein)<smiles>C=O</smiles>

(Formaldehyde)<smiles>CC(C)=O</smiles>

(Acetone)
Fig. 2. List of toxicant contents generated from tobacco-based waterpipe smoking, according to Shihadeh et al. [5]. Adapted from Shihadeh et al. Tob Control 2015;24(Suppl 1):i22-30 [5]. induce the oxidative stress status in humans, increase the expression of carcinogenic genes, and disruption of the physiological activity of internal organs, especially those of the respiratory and cardiovascular systems $[3,7]$. The amount of nicotine present in unflavored tobacco is ten times more than flavored tobacco (maassal) as shown by gas chromatography, and it was suggested that the reason behind lower nicotine content in flavored maassal is the addition of honey, glycerin and other flavors that contributed in minimizing the tobacco content of maassal [8]. The secondhand smokers could retain up to $80 \%$ of nicotine, and the same amount of exhaled carbon monoxide in comparison with the active waterpipe smokers [9]. Another meta-analysis study illustrated that waterpipe smokers could induce the tumor biomarkers in cigarette smokers. Also, waterpipe smoking (WPS) is highly suspected in inducing head and neck, esophagus, and lung cancer [10]. Consumption of antioxidants is one of the top strategies that contribute to attenuate the oxidative stress 
status induced by the toxicants. Antioxidants are chemical compounds extracted from natural sources, especially medicinal plants. These compounds can react with the reactive oxygenic and nitrogenic species to prevent these free radicals from damaging the cellular component of different tissues $[11,12]$.

Curcumin (CUM) is a phytopolyphenol pigment isolated from the plant Curcuma longa, commonly known as turmeric, with a variety of pharmacologic properties. CUM has molecular formula of $\mathrm{C}_{21} \mathrm{H}_{20} \mathrm{O}_{6}$ and molecular weight of $368.4 \mathrm{~g} / \mathrm{mol}$ (Fig. 1B) [1]. This molecule has antioxidant capacity by preventing the formation of reactive oxygen species, possesses anti-inflammatory properties as a result of inhibition of cyclooxygenases and other enzymes involved in inflammation [13]. Also, CUM has anti-carcinogenic activity by inhibiting proliferation of tumor cells, suppression of chemically induced carcinogenesis and tumor growth in animal models of cancer [14]. CUM inhibits toxin-mediated stress responses via its anti-inflammatory and antioxidant properties in addition to inducing the expression of cytoprotective proteins [15]. CUM neutralizes nitric oxide, provides continuity to antioxidant enzymes such as catalase and superoxide dismutase, and lowers lipid peroxidation, to protect tissues and organs from oxidative damage caused by nicotine [16].

Caffeic acid (CAF [3,4-Dihydroxycinnamic acid]) is an organic compound found naturally in plants such as argan oil, oats, wheat, rice, olive oil, and narrow-leaved purple coneflower. It has molecular formula of $\mathrm{C}_{9} \mathrm{H}_{8} \mathrm{O}_{4}$ and molecular weight of $180.16 \mathrm{~g} / \mathrm{mol}$ (Fig. 1C) [1] and exhibit potent antioxidant activity [17]. CAF showed antioxidant and chemo preventive properties against toxic chemical models in vivo and in vitro [18]. In vivo, CAF showed enhancement of reproductive functions in male rats by increasing the concentration of testicular zinc, glycogen, cholesterol, and hydroxysteroid dehydrogenases, increasing superoxide dismutase and total thiol in the epididymis and stimulating the secretion of testosterone and follicle-stimulating hormone [19]. Also, CAF attenuates titanium dioxide nanoparticles toxicity by decreasing DNA damage and possesses renal and hepatoprotective functions [20]. In vitro, CAF reduces reactive oxygen species level, attenuates lipid peroxidation, elevates cellular glutathione content, and increases cellular viability in cultured hepatocytes induced by hydrogen peroxide toxicity [21, 22]. CAF showed anti-cancer properties by inhibiting the migration of breast cancer cell line (MCF7) and reducing its cellular viability [23]. In addition, CAF has antimicrobial ac- tivity by promoting intracellular potassium leakage, changes physiochemical properties of surface membrane which consequently lead to cell death [24]. CAF showed antiviral properties by inhabiting replication and propagation of hepatitis C virus [25].

In this study, we aim to evaluate the cytoprotective effect of CUM and CAF against second-hand smoking model induced by waterpipe tobacco smoking using a modified smoking machine. The experimental exposure lasts for two consecutive weeks in parallel with CUM and CAF administration. Immunochemical inflammatory biomarker includes interleukin-1 beta (IL-1 $\beta$ ), interleukin-6 (IL-6), and tumor necrosis factor-alpha (TNF- $\alpha$ ), and biochemical tests for liver and kidney functions include alanine aminotransferase (ALT), aspartate aminotransferase (AST), lactate dehydrogenase (LDH), creatinine, and blood urea nitrogen (BUN) were investigated. Five microns stained sections from the heart, kidney, and lung were examined under the light microscope to evaluate the histopathological changes.

\section{Materials and Methods}

\section{Experimental animals}

Adult male albino BALB/c mice (eight weeks old, weight $22 \pm 3 \mathrm{~g}$ ) were purchased from the animal care unit at Jordan University of Science and Technology, Irbid, Jordan. Mice were acclimatized in room temperature with 12 hours light/ dark period for one week prior starting of the experiment. Mice were lived in semi-transparent plastic cages; each cage contains six or seven mice fed with standard chew and ad libitum for drinking water. The experiment was performed in Animal households in the Department of Biological Sciences at The University of Jordan, Amman, Jordan. The code of practice for the housing and care of animals used in scientific procedures was observed. All applicable guidelines for the care and use of animals at The University of Jordan were followed. All experimental protocols were approved by the Graduate Studies and Research Committee of the School of Science at the University of Jordan, Amman, Jordan.

Fifty-two adult male (8 weeks old) BALB/c albino mice were divided randomly into four different groups; each contains thirteen mice divided as following: Group 1 (Control) was intraperitoneally (IP) injected with vehicle solution and exposed to fresh air; Group 2 (WPS) was IP injected with vehicle solution and exposed to waterpipe tobacco smoking; Group 3 (WPS+CUM) was IP injected with $0.2 \mathrm{ml}(40 \mathrm{mg} /$ 
$\mathrm{kg} /$ day) of CUM prior to the exposure of waterpipe tobacco smoking; Group 4 (WPS+CAF) was IP injected with $0.2 \mathrm{ml}$ (40 mg/kg/day) of CAF prior to the exposure of waterpipe tobacco smoking.

\section{Preparation of antioxidants}

CUM and CAF were purchased from (Sigma-Aldrich, China) with high purity. Stock solutions of these chemicals were prepared according to manufacturer instruction using ethanol as dissolving agent. Working solutions were prepared by using phosphate-buffered saline ( $\mathrm{pH} 7.2,0.1 \mathrm{M}$ ) as vehicle in the same day of exposure to ensure the significant bioactivity of the prepared antioxidants, with making considerations that the experimental dose was $40 \mathrm{mg} / \mathrm{kg} /$ day for both CUM and CAF according to $[26,27]$. These solutions were packed in $1 \mathrm{ml}$ disposable insulin syringes.

\section{Tobacco honeyed-maassal and waterpipe preparation}

Tobacco Honeyed-Maassal was purchased from available local markets (Two Apples Flavoured Molasses, Mazaya, Jordan). Waterpipe instrument is composed of four main parts: Head bowl, body with neck, glass vase and hose with mouthpiece (Fig. 1A) [1]. Five grams of maassal was uploaded to waterpipe head and the vase was half filled with tape water. The mouthpiece was cleaned with 75\% alcohol every day. For burning tobacco, one fast lighting disk charoal $40 \mathrm{~mm}$ was burned upon a perforated aliminium foil covering the waterpipe head.

\section{Smoking exposure}

Each group of mice exposed to waterpipe tobacco smoking was placed inside transparent plexiglass box $\left(0.6 \times 0.5 \times 0.1 \mathrm{~m}^{3}\right)$ acting as inhalation chamber to perform the smoking process using a modified smoking machine described by Shraideh et al. [28]. After placing mice inside the inhalation chamber, a vacuum pump withdraws smoke from burned waterpipe tobacco inside the chamber to provide a smoky environment (each group was exposed individually to prevent mixing). Smoking procedure was 15 minutes in duration with 15 smoking intervals (10 seconds WPS puff +50 seconds stop puffing with adequate ventilation).

\section{Blood collection and serum separation}

The chew and ad libitum were removed from the cages in the night of the 14th day of the exposure. Next morning, fasting blood was collected from mice by introducing non- heparinized capillary into the retro orbital venous sinus. Blood droplets flew into the Eppendorf tube, left in room temperature at dark condition for one hour, then centrifugated at 3,800 rpm for 10 minutes. The resulting pale-yellow supernatant was the designated serum. The serum was collected carefully by micropipette without up-taking the coagulated red blood cells and transferred it into new disposablelabeled Eppendorf tube.

\section{Liver and kidney biochemical tests}

Three common tests were performed to evaluate liver function include (ALT, AST, and LDH) with two tests for kidney function tests (creatinine and blood urea nitrogen BUN) using serum samples. ALT and AST kits were purchased from (Teco Diagnostics, Annaheim, CA, USA), creatinine and BUN (BioSystems, Barcelona, Spain). These tests were operated using UV/VIS single beam spectrophotometer (EMC-11D-V; EMCLAB instruments, Duisburg, Germany). LDH test was operated through automated clinical chemistry analyzer (HumaStar 600, Human Diagnostics, Wiesbaden, Germany).

\section{Histological samples}

After blood collection, the mice were euthanized by cervical dislocation. Heart, kidney, and lungs were isolated from mice, washed with phosphate buffered saline, and fixed in $10 \%$ formal saline. Tissue specimens were dehydrated with ascending concentrations of ethanol, cleared with xylene, and impregnated in paraffin wax using automated processor (Citadel 2000 Tissue Processor; Thermo Scientific Shandon, Loughborough, UK). These specimens were embedded in paraffin wax, sectioned with $5 \mu \mathrm{m}$ thickness using manual rotary microtome (Leica RM2125RT, Leica Biosystems, Wetzlar, Germany), stained using the hematoxylin and eosin $\mathrm{Y}$ (BioGnost, Zagreb, Croatia), mounted in DPX. Stained sections were microphotographed by (Leica inverted light microscopy, Leica Microsystems, Wetzlar, Germany) installed with colored digital camera (Leica EC3; Leica Microsystems, Heerburg, Switzerland) and monitored manually by computer software (Leica Application Suite LAS EZ version 3.4.0, Leica Microsystems).

\section{Immunochemical tests for proinflammatory cytokines}

Three ELISA kits were purchased from (Abcam, UK) to measure the levels of IL-1 $\beta$, IL- 6 , and TNF- $\alpha$ in mice serum. All procedures were performed according to the instructions 
written in manual sheets. All plates were read using microplate reader (RT-2100C, Rayto, Shenzhen, China).

\section{Statistical analysis}

The results were inserted in (GraphPad Prism version 7.0.0; GraphPad Software Inc., San Diego, CA, USA) for statistical analysis and designing the bar graphs. All data for the treatment groups for each test were analyzed by one-way ANOVA followed by the post comparison test using Tukey post-hoc, considering results with $P$-value $<0.05$, $<0.01,<0.001$ as significant, highly significant and extreme significant respectively. The graphs were represented as mean \pm standard error of the mean.

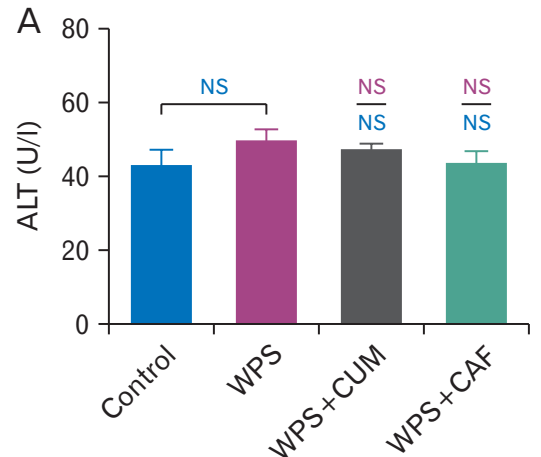

Treatment groups

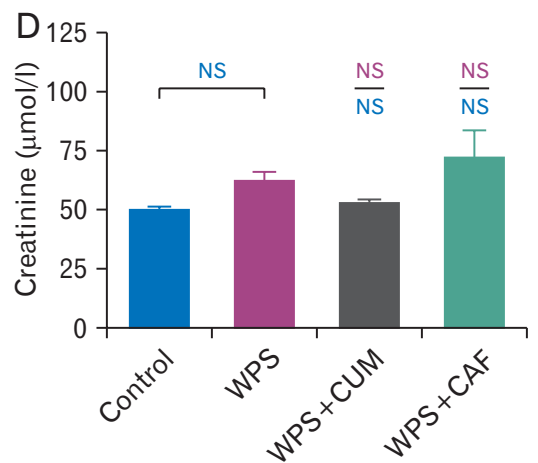

Treatment groups

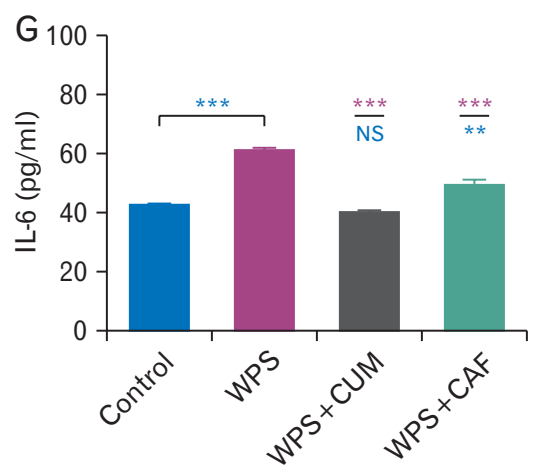

Treatment groups

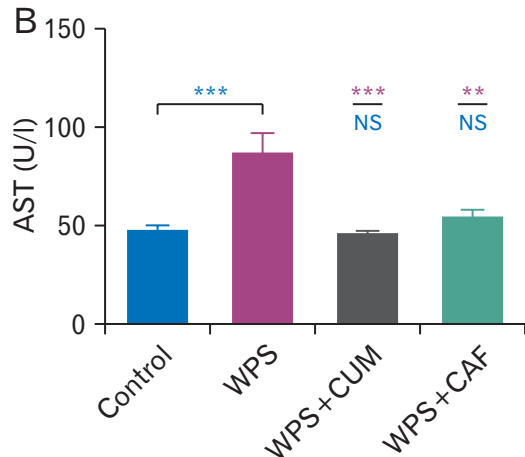

Treatment groups

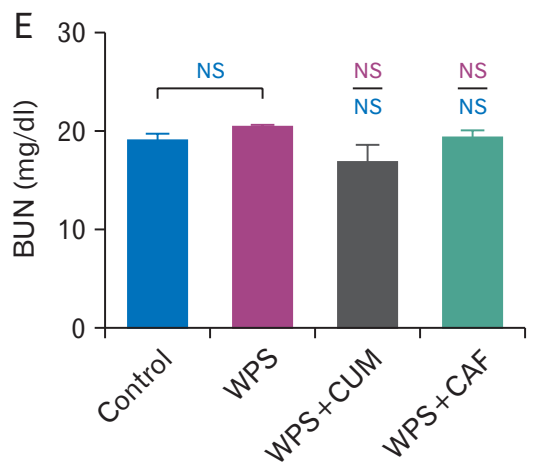

Treatment groups

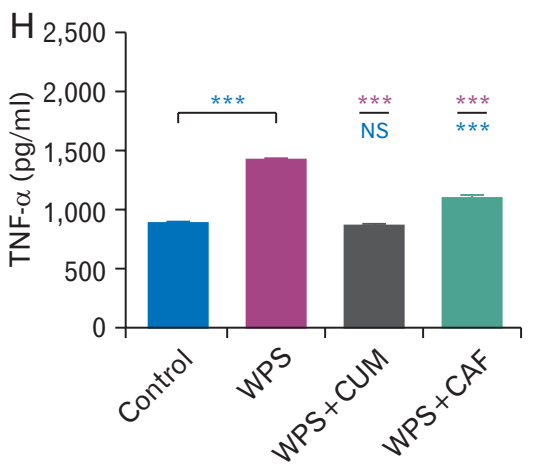

Treatment groups
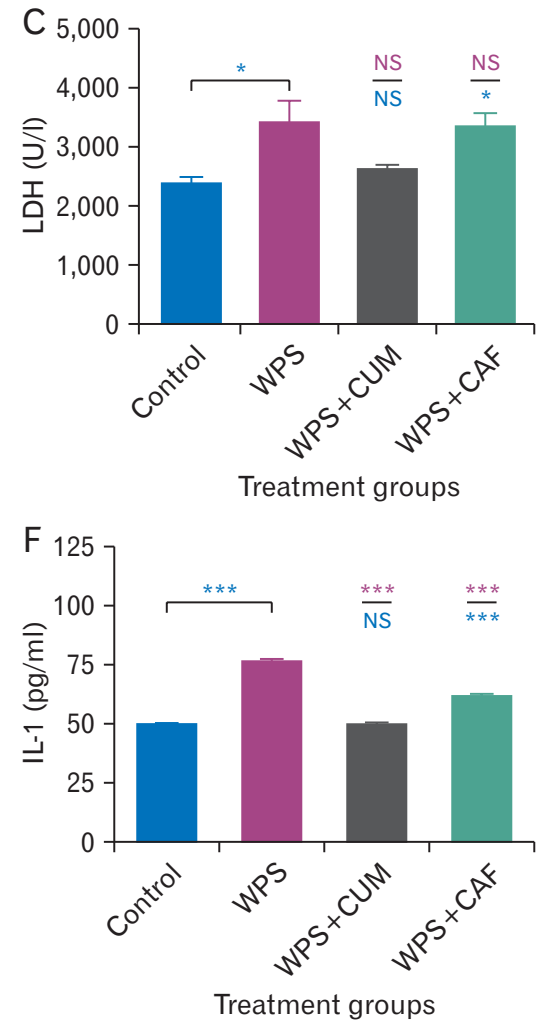

Fig. 3. Bar charts for illustration level of different liver function, kidney function, and proinflammatory cytokines in serum samples of albino mice; (A) for the concentration of ALT; (B) for the concentration of AST; (C) for the concentration of LDH; (D) for quantifying the level of creatinine; (E) for the level of BUN; (F) shows the level for IL-1 $\beta$; (G) shows the level for IL-6, and (H) shows the level for TNF- $\alpha$. Asterisks (*, $\left.{ }^{* *},{ }^{* * *}\right)$ indicates for $(P<0.05, P<0.01, P<0.001)$ respectively, and (NS) indicates for no significant result when $P \geq 0.05$. Significance against the control group written in blue color, whereas against WPS group written in red. WPS, WPS+CUM, and WPS+CAF respectively. ALT, alanine aminotransferase; AST, aspartate aminotransferase; BUN, blood urea nitrogen; CAF, caffeic acid; CUM, curcumin; IL-1 $\beta$, interleukin-1 beta; IL-6, interleukin-6; LDH, lactate dehydrogenase; NS, not significant; TNF- $\alpha$, tumor necrosis factor-alpha; WPS, waterpipe smoking. 


\section{Results}

\section{Liver and kidney function tests}

The results for ALT enzyme did not show any significant differences among the examined groups at $P<0.05$ (Fig. 3A). The results for AST enzyme were $(47 \pm 3.2 \mathrm{U} / 1,86 \pm 10.3 \mathrm{U} /$ 1, 44 $\pm 2.8 \mathrm{U} / 1,53 \pm 4.6 \mathrm{U} / \mathrm{l})$ for Control, WPS, WPS+CUM and WPS+CAF respectively (Fig. 3B). WPS group showed extreme significant result against Control group at $P<0.001$. WPS+CUM group did not show a significant change against Control group but had extreme significant result against WPS group at $P<0.001$. WPS + CAF group did not show a significant change against Control group but had highly significant result against WPS group at $P=0.003$.

The results for LDH enzyme were $2,366 \pm 119 \mathrm{U} / \mathrm{l}$, $3,408 \pm 386 \mathrm{U} / 1,2,609 \pm 89 \mathrm{U} / 1,3,325 \pm 250 \mathrm{U} / 1$ for Control, WPS, WPS+CUM and WPS+CAF respectively (Fig. 3C). WPS group showed significant difference against Control group at $P=0.023$. WPS + CUM group did not show significant differences against both the Control and WPS groups at $P<0.05$. WPS $+C A F$ showed a significant difference against Control group at $P=0.042$ and did not show a significant difference against WPS group at $P<0.05$ (Fig. 3C).

The results for two kidney function tests (creatinine and BUN) were $49.5 \pm 2.15 \mu \mathrm{mol} / \mathrm{l}, 61.5 \pm 4.47 \mu \mathrm{mol} / \mathrm{l}, 52.3 \pm 1.86$ $\mu \mathrm{mol} / 1,71.5 \pm 11.8 \mu \mathrm{mol} / \mathrm{l}$ for Control, WPS, WPS+CUM and WPS+CAF groups respectively in creatinine test (Fig. $3 \mathrm{D}$ ), and $11.9 \pm 0.77 \mathrm{mg} / \mathrm{dl}, 20.3 \pm 0.17 \mathrm{mg} / \mathrm{dl}, 16.7 \pm 1.89 \mathrm{mg} /$ $\mathrm{dl}, 19.2 \pm 0.79 \mathrm{mg} / \mathrm{dl}$ for Control, WPS, WPS+CUM and WPS+CAF groups respectively in BUN test (Fig. 3E). The statistical results did not show significant differences among the groups in both creatinine and BUN tests.

\section{Immunochemical tests for proinflammatory cytokine biomarkers}

The results for IL- $1 \beta$ marker were $49.2 \pm 0.91 \mathrm{pg} / \mathrm{ml}$, $76.0 \pm 1.07 \mathrm{pg} / \mathrm{ml}, 49.1 \pm 0.92 \mathrm{pg} / \mathrm{ml}, 60.9 \pm 1.63 \mathrm{pg} / \mathrm{ml}$ for Control, WPS, WPS+CUM, and WPS+CAF respectively (Fig. 3F). WPS group showed extreme significant difference against Control group at $P<0.001$. WPS+CUM group did not show significant difference against Control group but had extreme significant difference against WPS group at $P<0.001$. WPS+CAF group showed extreme significant differences against both the Control and WPS groups at $P<0.001$ (Fig. 3F).

The results for IL- 6 marker were $42.1 \pm 0.81 \mathrm{pg} / \mathrm{ml}$, $60.3 \pm 1.51 \mathrm{pg} / \mathrm{ml}, 40.2 \pm 0.85 \mathrm{pg} / \mathrm{ml}, 49.1 \pm 1.90 \mathrm{pg} / \mathrm{ml}$ for Control, WPS, WPS+CUM, and WPS+CAF respectively (Fig. $3 G)$. WPS group showed extreme significant difference against Control group at $P<0.001$. WPS + CUM group did not show significant difference against Control group but

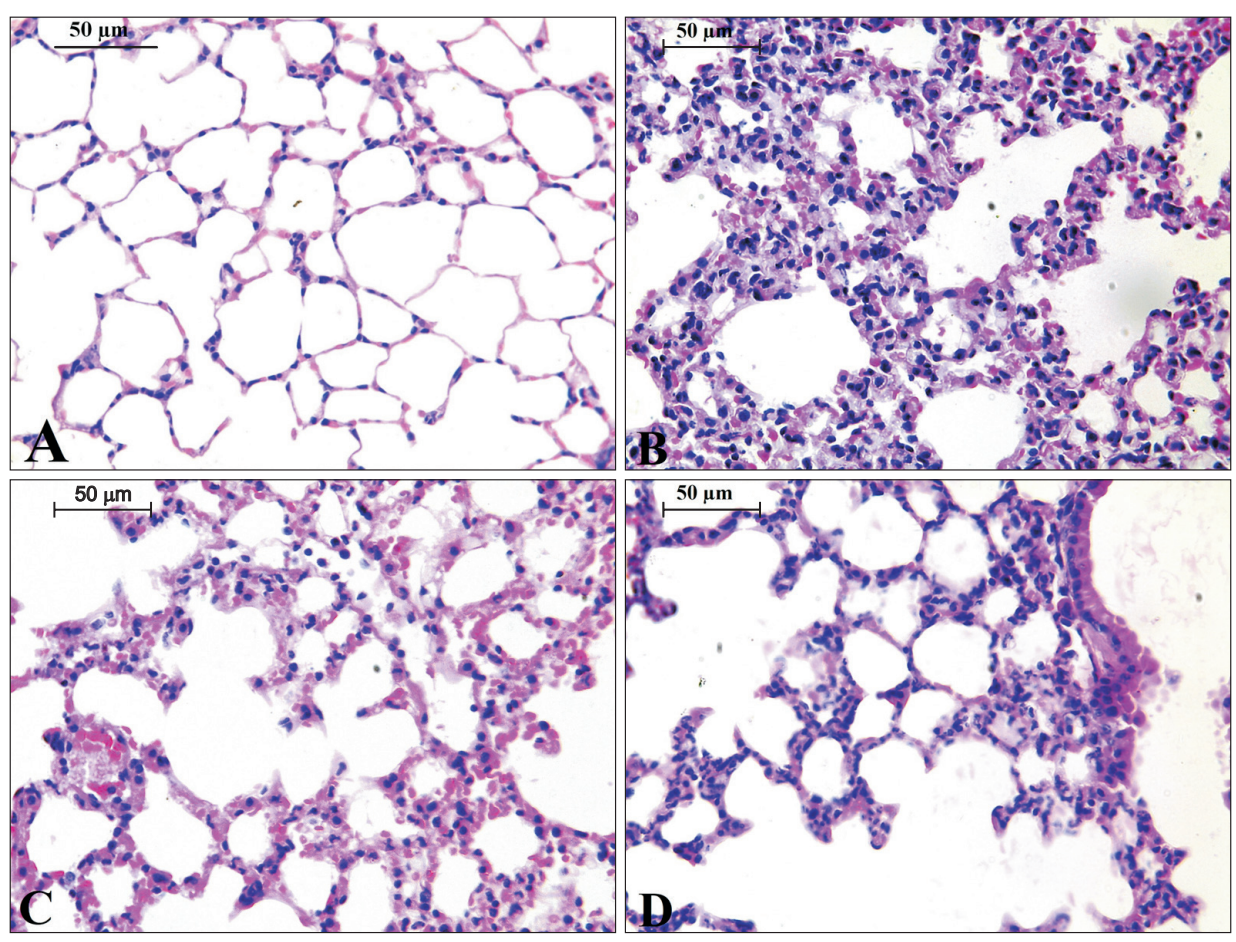

Fig. 4. Thin sections of $5 \mu \mathrm{m}$ for the lung of different experimental groups in this study; (A) represents the control group; (B) for WPS; (C) for CUM+WPS; (D) for CAF+WPS. CAF, caffeic acid; CUM, curcumin; WPS, waterpipe smoking. Sections were stained with $\mathrm{H} \& \mathrm{E}$, magnification, $\times 400$. Scale bars $=50 \mu \mathrm{m}, \mathrm{n}=13(\mathrm{~A}-\mathrm{D})$. 
had extreme significant difference against WPS group at $P<0.001$. WPS + CAF group showed highly significant difference against Control group at $P=0.004$ and extreme significant difference against WPS group at $P<0.001$ (Fig. 3G).

The results for TNF- $\alpha$ marker were $881 \pm 14 \mathrm{pg} / \mathrm{ml}$, $1,413 \pm 22 \mathrm{pg} / \mathrm{ml}, 859 \pm 13 \mathrm{pg} / \mathrm{ml}, 1,086 \pm 39 \mathrm{pg} / \mathrm{ml}$ for Control, WPS, WPS+CUM, and WPS+CAF respectively (Fig. $3 \mathrm{H}$ ). WPS group showed extreme significant difference against Control group at $P<0.001$. WPS+CUM group did not show significant difference against Control group but had extreme significant difference against WPS group at $P<0.001$. WPS + CAF group showed extreme significant differences against both the Control and WPS groups at $P<0.001$ (Fig. $3 \mathrm{H})$.

\section{Comparative histopathological description for the selected organs in this study}

The control group sections showed regular spaces of alveolar sacs, alveolar septa were integral, alveolar walls were well-inflated and blood vessels had normal endothelial cells without dilations in smooth muscles (Fig. 4A). WPS group showed thickening of alveolar walls, alveolar spaces were collapsed and not properly inflated, sort of nuclear condensation and cellular vacuolization, bleeding of RBCs and infiltration of inflammatory cells (Fig. 4B). WPS+CUM group showed less infiltration of inflammatory cells, alveoli were better inflated and less thickening in comparison to WPS group, but bleeding and hemorrhage were still observed (Fig. 4C). WPS+CAF group showed well inflated alveoli, less alveolar vacuolization, less hemorrhage and bleeding, but has significant infiltration of inflammatory cells (Fig. 4D).

The control group showed well developed cardiac muscle fibers without deterioration or inflammation (Fig. 5A). WPS group showed partial degradation and disintegration of cardiac myofiber, nuclei of cardiomyocytes displayed necrotic features and partial vacuolization in the sarcoplasm, mild myofibrillar spaces and mild blood congestion in the interstitial fluid without significant infiltration of inflammatory cells (Fig. 5B). WPS+CUM group showed normal cardiomyocytes with euchromatic nuclei, compact myofibrils and obvious intercalated discs (Fig. 5C). WPS+CAF group showed normal of structure for cardiomyocytes with mild myofibril spaces without inflammation or hemorrhage (Fig. 5D).

Microscopic examination of the kidney revealed the normal structure of kidney cortex was free from any abnormalities (Fig. 6A). WPS group showed deteriorations in kidney cortex and dilation of collecting ducts, the epithelial cells with some necrotic nuclei containing condensed chromatin, epithelial vacuolization, and infiltration of inflammatory cells (Fig. 6B). WPS+CUM group showed blood conges-
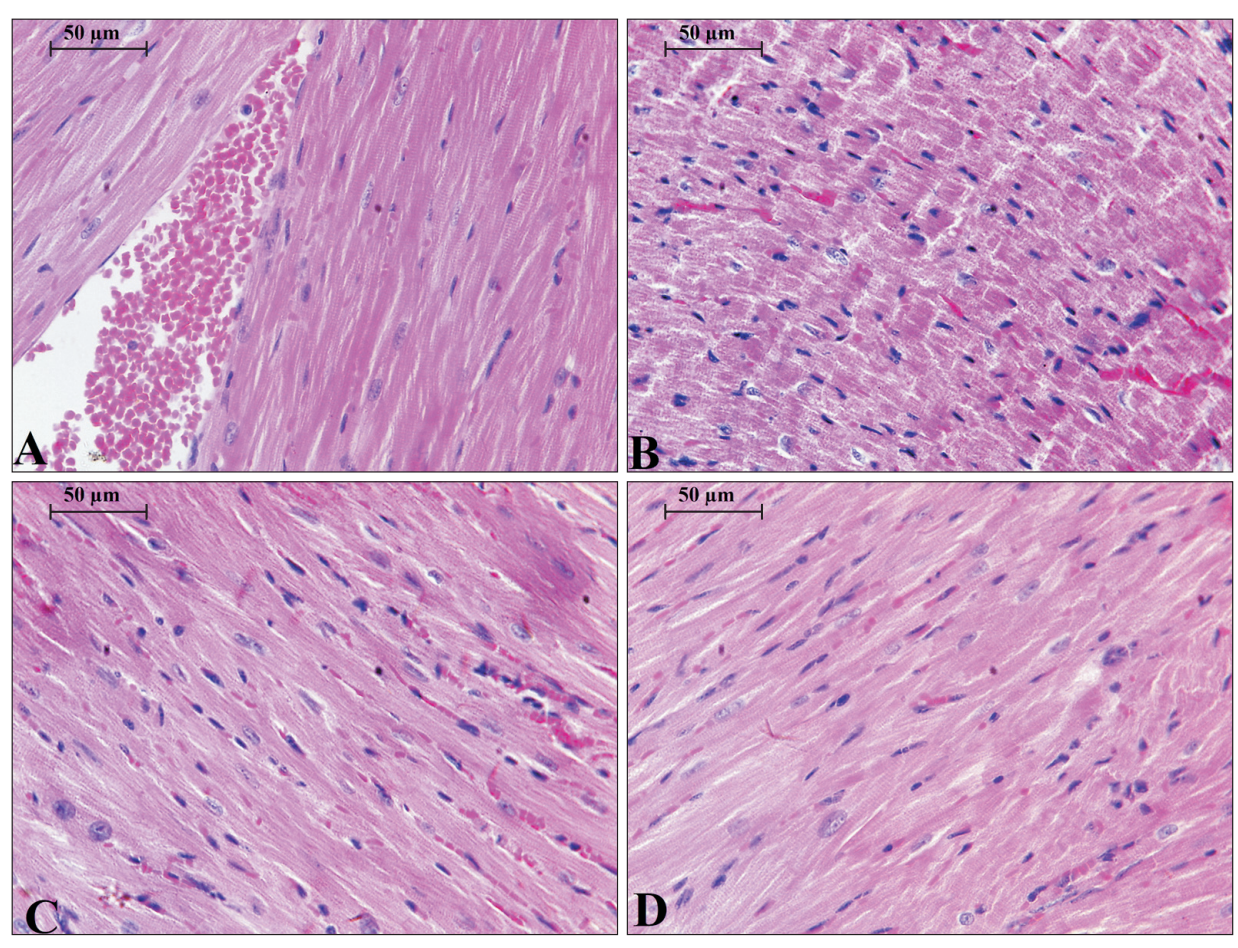

Fig. 5. Thin sections of $5 \mu \mathrm{m}$ for the heart of different experimental groups in this study; (A) represents the control group; (B) for WPS; (C) for CUM+WPS; (D) for CAF+WPS. CAF, caffeic acid; CUM, curcumin; WPS, waterpipe smoking. Sections were stained with $\mathrm{H} \& \mathrm{E}$, magnification, $\times 400$. Scale bars $=50 \mu \mathrm{m}, \mathrm{n}=13(\mathrm{~A}-\mathrm{D})$. 

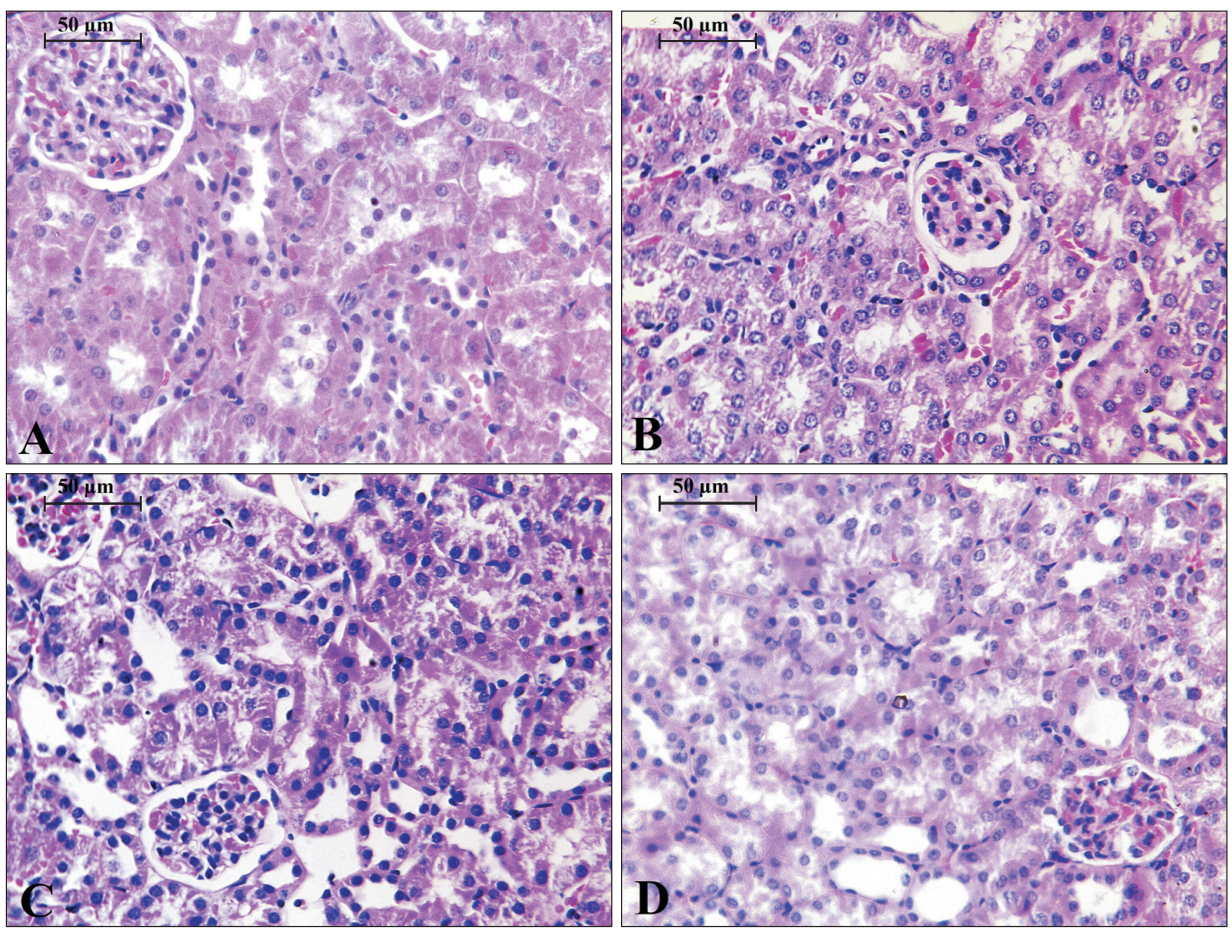

Fig. 6. Thin sections of $5 \mu \mathrm{m}$ for the kidney of different experimental groups in this study; (A) represents the control group; (B) for WPS; (C) for CUM+ WPS; (D) for CAF+WPS. CAF, caffeic acid; CUM, curcumin; WPS, waterpipe smoking. Sections were stained with $\mathrm{H} \& \mathrm{E}$, magnification, $\times 400$. Scale bars $=$ $50 \mu \mathrm{m}, \mathrm{n}=13$ (A-D).

tion, partial recovery of epithelium and glomerulus less vacuolization, significant decrease in number of counted necrotic nuclei with condensed chromatin (Fig. 6C). Kidney in WPS+CAF group showed slight deterioration in proximal not distilled convoluted tubules, no signs of vacuolization or necrotic nuclei in cells of cortex part of the kidney (Fig. 6D).

\section{Discussion}

There are common social views in middle eastern countries that waterpipe tobacco smoking is less harmful than cigarette smoking, especially among youth and teenagers. This study showed that short term exposure to waterpipe tobacco smoking could elevate liver enzymes, induce inflammatory cells, proinflammatory cytokines, and deteriorate the histological architecture of lung, heart, and kidney in albino mice without significant increasing in levels of creatinine and blood urea nitrogen. These results were congruent with previous findings that showed waterpipe tobacco smoking elevate total white blood cells count, significantly increase TNF- $\alpha$ and IL-6 in bronchoalveolar fluid lavage [29]. In addition, waterpipe tobacco smoking decreases the enzymatic activity of some endogenous free radical scavengers like superoxide dismutase, catalase, and glutathione peroxidase, and increases lipid peroxidation in mice [30]. Also, the influx of inflammatory cells in the peribronchial and interstitial spaces consisting predominantly of neutrophil polymorphs with increasing in the levels of 8-isoprostane, nuclear factor kappa-B, DNA migration, and significantly alters the physiological airway resistance in conducting portion of the lung in mice exposed to waterpipe tobacco smoking [31]. The impact of WPS in lung tissue of rat showed many morphological changes including induce the bleeding of red blood cell, thickening of alveolar walls, Furthermore, the inflammatory cells were increased [29]. In addition, short term exposure of WPS could induce vacuolization with mild glomerular degeneration, mild degeneration of endothelial cells of glomerulus capillaries, and mild ultrastructural changes in proximal convoluted tubules in mice kidney without significant increase in amount of creatinine clearance and proteins in urine [32]. Also, WPS showed histopathological alternations and ultrastructural changes in cardiomyocyte organelles in rat ventricular tissue [33].

Our findings showed that CUM had attenuated the cytotoxicity induced by waterpipe tobacco smoking by retaining the inflation of alveoli and decrease the infiltration of inflammatory cells in the lung, displayed normal cardiomyocytes with compact myofibrils and evident intercalated discs in heart, reduced the level of AST and LDH enzymes, but did not prevent the deteriorations of nephrons in the kidney. 
Previous studies stated that CUM has chemopreventive effect for human urothelial cells and human bladder carcinoma cells that induced by chronic exposure of cigarette smoking [34]. Also, CUM can abrogate the expression of genes of cyclin D1, matrix metalloproteinase-9, and act as COX-2 inhibitor in lung normal and carcinogenic cell lines exposed to cigarette smoking [35]. CUM could increase the transcription of antioxidant genes in primary alveolar macrophage, decrease the infiltration of inflammatory cells in bronchoalveolar lavage fluid, and reduce the enlargement of air space in lung of mice exposed to long-term of cigarette smoking [36].

CAF showed a chemopreventive action against alveolar thickening induced by WPS, reduces necrosis and vacuolization in cardiomyocytes, protects the typical architecture of the kidney to a reasonable extent, significantly decrease AST level in serum, but not LDH.

It was previously stated that CAF exhibits hepatoprotective activity through inhibiting the enzymatic activity of ALT and AST in rodents induced by the sub-lethal dose of paracetamol [37]. It was previously illustrated that CAF has potent inhibition on microsomal P450 cytochrome enzymes in human liver by acting as noncompetitive inhibitor to CYP1A2 enzyme and competitive inhibitor to CYP2C9 and CYP2D6 [38]. CAF has less ability than CUM in inhibiting 12-O-tetradecanoylphorbol-13-acetate-induced inflammation and promotion of skin tumors [39]. Moreover, CAF has more potent to inhibit lipid peroxidation than CUM [39].

Inflammation is major to the body's immunity against infection action. Besides, it is likewise a basic part of ordinary tissue repair. Tobacco smoking has been appeared to modify the host reaction and, in this way, alters the progression and result of irritation. The specific components of tobacco smoking prompting irritation are not obviously comprehended. Not with standing, it has been proposed that smoking influences various inflammatory process through its impact on immune inflammatory cells, causing an immunosuppressant state and cytokine secretion [40]. Several investigations revealed that tobacco smoke presentation is related with expanded inflammation. It has been discovered that the degree of serum inflammatory marker, for example, TNF- $\alpha$ is altogether higher in smokers contrasted with nonsmokers [41, 42]. The present research gave experimental evidence that exposure to WPS induces systemic inflammation and oxidative stress. Critically, we demonstrated that treatment with the nourishment added substance CUM and caffeic corrosive reduced the systemic inflammation [43, 44]. Nutritional compounds that show anti-inflammatory and antioxidant agent impacts have explicit applications in forestalling oxidative stress related injury [45].

We have as of late exhibited that exposure to WPS for 5 days and one month induced inflammation and oxidative stress in some studied organs [46, 47]. Therefore, in this study, the levels of inflammatory markers, for example, IL$1 \beta$, IL- 6 and TNF- $\alpha$, were estimated in serum of water pipe smoking with and without of CUM and CAF and we found that CUM and CAF attenuate the increase in serum concentrations of IL-1 $\beta$, IL- 6 and TNF- $\alpha$ caused by a two weeks acute secondhand exposure to WPS, suggesting the systemic anti-inflammatory effects of CUM and CAF. Besides, CUM showed better results than CAF in term of anti-inflammatory effect.

In conclusion, this study illustrated that both CUM and CAF had anti-inflammatory effect against the elevated levels of proinflammatory cytokines induced by exposure to waterpipe tobacco smoking. In addition, both antioxidants had ameliorative effects against the histopathological alternations induced by acute secondhand exposure of waterpipe tobacco smoking.

\section{ORCID}

Alia Khwaldeh: https://orcid.org/0000-0002-7492-4906

Ali Abu Siyam: https://orcid.org/0000-0002-6672-6184

Ahmed Alzbeede: https://orcid.org/0000-0002-1009-5440

Mohammad Farajallah:

https://orcid.org/0000-0002-1858-5348

Ziad Shraideh: https://orcid.org/0000-0002-3194-3728

Darwish Badran: https://orcid.org/0000-0002-8117-1762

\section{Author Contributions}

Conceptualization: AK, AAl. Data acquisition: AK, AAb, AAl, MF. Data analysis or interpretation: AAl, AK, ZS, DB. Drafting of the manuscript: $\mathrm{AK}, \mathrm{AAb}, \mathrm{AAl}$. Critical revision of the manuscript: MF, ZS, DB. Approval of the final version of the manuscript: all authors.

\section{Conflicts of Interest}

No potential conflict of interest relevant to this article was reported. 


\section{Acknowledgements}

We like to thank the Department of Biological Sciences at The University of Jordan for the technical facilitation to accomplish this work.

\section{References}

1. Bhatnagar A, Maziak W, Eissenberg T, Ward KD, Thurston G, King BA, Sutfin EL, Cobb CO, Griffiths M, Goldstein LB, Rezk-Hanna M. Water pipe (hookah) smoking and cardiovascular disease risk: a scientific statement From the American Heart Association. Circulation 2019;139:e917-36.

2. WHO Study Group on Tobacco Product Regulation (TobReg). Waterpipe tobacco smoking: health effects, research needs and recommended actions for regulators. 2nd ed. Geneva: WHO; 2015.

3. Jukema JB, Bagnasco DE, Jukema RA. Waterpipe smoking: not necessarily less hazardous than cigarette smoking: possible consequences for (cardiovascular) disease. Neth Heart J 2014;22:91-9.

4. Kaplan B, Sussan T, Rule A, Moon K, Grau-Perez M, Olmedo P, Chen R, Carkoglu A, Levshin V, Wang L, Watson C, Blount B, Calafat AM, Jarrett J, Caldwell K, Wang Y, Breysse P, Strickland P, Cohen J, Biswal S, Navas-Acien A. Waterpipe tobacco smoke: characterization of toxicants and exposure biomarkers in a cross-sectional study of waterpipe employees. Environ Int 2019;127:495-502.

5. Shihadeh A, Schubert J, Klaiany J, El Sabban M, Luch A, Saliba NA. Toxicant content, physical properties and biological activity of waterpipe tobacco smoke and its tobacco-free alternatives. Tob Control 2015;24(Suppl 1):i22-30.

6. Pryor WA, Stone K, Zang LY, Bermúdez E. Fractionation of aqueous cigarette tar extracts: fractions that contain the tar radical cause DNA damage. Chem Res Toxicol 1998;11:441-8.

7. Alsaad AM, Al-Arifi MN, Maayah ZH, Attafi IM, Alanazi FE, Belali OM, Alhoshani A, Asiri YA, Korashy HM. Genotoxic impact of long-term cigarette and waterpipe smoking on DNA damage and oxidative stress in healthy subjects. Toxicol Mech Methods 2019;29:119-27.

8. Hadidi KA, Mohammed FI. Nicotine content in tobacco used in hubble-bubble smoking. Saudi Med J 2004;25:912-7.

9. Chaouachi K. Hookah (Shisha, Narghile) smoking and environmental tobacco smoke (ETS). A critical review of the relevant literature and the public health consequences. Int J Environ Res Public Health 2009;6:798-843.

10. Mamtani R, Cheema S, Sheikh J, Al Mulla A, Lowenfels A, Maisonneuve P. Cancer risk in waterpipe smokers: a metaanalysis. Int J Public Health 2017;62:73-83.

11. Zhang YJ, Gan RY, Li S, Zhou Y, Li AN, Xu DP, Li HB. Antioxidant phytochemicals for the prevention and treatment of chronic diseases. Molecules 2015;20:21138-56.
12. Tan BL, Norhaizan ME, Liew WP, Sulaiman Rahman H. Antioxidant and oxidative stress: a mutual interplay in age-related diseases. Front Pharmacol 2018;9:1162.

13. Bengmark S. Curcumin, an atoxic antioxidant and natural NFkappaB, cyclooxygenase-2, lipooxygenase, and inducible nitric oxide synthase inhibitor: a shield against acute and chronic diseases. JPEN J Parenter Enteral Nutr 2006;30:45-51.

14. Oyagbemi AA, Saba AB, Ibraheem AO. Curcumin: from food spice to cancer prevention. Asian Pac J Cancer Prev 2009;10:963-7.

15. Bisht K, Wagner KH, Bulmer AC. Curcumin, resveratrol and flavonoids as anti-inflammatory, cyto- and DNA-protective dietary compounds. Toxicology 2010;278:88-100.

16. Kalpana C, Sudheer AR, Rajasekharan KN, Menon VP. Comparative effects of curcumin and its synthetic analogue on tissue lipid peroxidation and antioxidant status during nicotineinduced toxicity. Singapore Med J 2007;48:124-30.

17. Stojković D, Petrović J, Soković M, Glamočlija J, KukićMarković J, Petrović S. In situ antioxidant and antimicrobial activities of naturally occurring caffeic acid, p-coumaric acid and rutin, using food systems. J Sci Food Agric 2013;93:3205-8.

18. Khan FA, Maalik A, Murtaza G. Inhibitory mechanism against oxidative stress of caffeic acid. J Food Drug Anal 2016;24:695702.

19. Akomolafe SF, Akinyemi AJ, Oboh G, Oyeleye SI, Ajayi OB, Omonisi AE, Owolabi FL, Atoyebi DA, Ige FO, Atoki VA. Coadministration of caffeine and caffeic acid alters some key enzymes linked with reproductive function in male rats. Andrologia 2018;50:e12839.

20. Dekanski D, Spremo-Potparević B, Bajić V, Živković L, Topalović D, Sredojević DN, Lazić V, Nedeljković JM. Acute toxicity study in mice of orally administrated $\mathrm{TiO} 2$ nanoparticles functionalized with caffeic acid. Food Chem Toxicol 2018;115:42-8.

21. Li Y, Chen LJ, Jiang F, Yang Y, Wang XX, Zhang Z, Li Z, Li L. Caffeic acid improves cell viability and protects against DNA damage: involvement of reactive oxygen species and extracellular signal-regulated kinase. Braz J Med Biol Res 2015;48:5028.

22. Ahn CB, Je JY, Kim YS, Park SJ, Kim BI. Induction of Nrf2mediated phase II detoxifying/antioxidant enzymes in vitro by chitosan-caffeic acid against hydrogen peroxide-induced hepatotoxicity through JNK/ERK pathway. Mol Cell Biochem 2017;424:79-86.

23. Kabała-Dzik A, Rzepecka-Stojko A, Kubina R, Wojtyczka RD, Buszman E, Stojko J. Caffeic acid versus caffeic acid phenethyl ester in the treatment of breast cancer MCF-7 cells: migration rate inhibition. Integr Cancer Ther 2018;17:1247-59.

24. Andrade M, Benfeito S, Soares P, Magalhães e Silva D, Loureiro J, Borges A, Borges F, Simões M. Fine-tuning of the hydrophobicity of caffeic acid: studies on the antimicrobial activity against Staphylococcus aureus and Escherichia coli. RSC Adv 2015;5:53915-25.

25. Tanida I, Shirasago Y, Suzuki R, Abe R, Wakita T, Hanada K, 
Fukasawa M. Inhibitory effects of caffeic acid, a coffee-related organic acid, on the propagation of hepatitis C virus. Jpn J Infect Dis 2015;68:268-75.

26. Zhu Q, Sun Y, Yun X, Ou Y, Zhang W, Li JX. Antinociceptive effects of curcumin in a rat model of postoperative pain. Sci Rep 2014;4:4932.

27. Salem AM, Ragheb AS, Hegazy MGA, Matboli M, Eissa S. Caffeic acid modulates miR-636 expression in diabetic nephropathy rats. Indian J Clin Biochem 2019;34:296-303.

28. Shraideh ZA, Awaida W, Najjar H, Musleh M. A modified smoking machine for monitoring the effect of tobacco smoke on albino rats. Jordan J Biol Sci 2011;4:109-12.

29. Khabour OF, Alzoubi KH, Bani-Ahmad M, Dodin A, Eissenberg T, Shihadeh A. Acute exposure to waterpipe tobacco smoke induces changes in the oxidative and inflammatory markers in mouse lung. Inhal Toxicol 2012;24:667-75.

30. Al-Sawalha NA, Alzoubi KH, Khabour OF, Alyacoub W, Almahmood Y. Effect of waterpipe tobacco smoke exposure during lactation on learning and memory of offspring rats: role of oxidative stress. Life Sci 2019;227:58-63.

31. Nemmar A, Al-Salam S, Beegam S, Yuvaraju P, Ali BH. Waterpipe smoke exposure triggers lung injury and functional decline in mice: protective effect of Gum Arabic. Oxid Med Cell Longev 2019;2019:8526083.

32. Nemmar A, Beegam S, Yuvaraju P, Yasin J, Ali BH, Adeghate E. Nose-only water-pipe smoke exposure in mice elicits renal histopathological alterations, inflammation, oxidative stress, DNA damage, and apoptosis. Front Physiol 2020;11:46.

33. Al-Awaida W, Najjar H, Shraideh Z. Structural characterization of rat ventricular tissue exposed to the smoke of two types of waterpipe. Iran J Basic Med Sci 2015;18:942-9.

34. Liang Z, Lu L, Mao J, Li X, Qian H, Xu W. Curcumin reversed chronic tobacco smoke exposure induced urocystic EMT and acquisition of cancer stem cells properties via Wnt/ $\beta$-catenin. Cell Death Dis 2017;8:e3066.

35. Shishodia S, Majumdar S, Banerjee S, Aggarwal BB. Ursolic acid inhibits nuclear factor-kappaB activation induced by carcinogenic agents through suppression of IkappaBalpha kinase and p65 phosphorylation: correlation with down-regulation of cyclooxygenase 2, matrix metalloproteinase 9, and cyclin D1. Cancer Res 2003;63:4375-83.

36. Suzuki M, Betsuyaku T, Ito Y, Nagai K, Odajima N, Moriyama C, Nasuhara Y, Nishimura M. Curcumin attenuates elastase- and cigarette smoke-induced pulmonary emphysema in mice. Am J Physiol Lung Cell Mol Physiol 2009;296:L614-23.

37. Janbaz KH, Saeed SA, Gilani AH. Studies on the protective effects of caffeic acid and quercetin on chemical-induced hepatotoxicity in rodents. Phytomedicine 2004;11:424-30.

38. Rastogi H, Jana S. Evaluation of inhibitory effects of caffeic acid and quercetin on human liver cytochrome p450 activities. Phytother Res 2014;28:1873-8.

39. Anand P, Thomas SG, Kunnumakkara AB, Sundaram C, Harikumar KB, Sung B, Tharakan ST, Misra K, Priyadarsini IK, Rajasekharan KN, Aggarwal BB. Biological activities of curcumin and its analogues (Congeners) made by man and Mother Nature. Biochem Pharmacol 2008;76:1590-611.

40. Gonçalves RB, Coletta RD, Silvério KG, Benevides L, Casati MZ, da Silva JS, Nociti FH Jr. Impact of smoking on inflammation: overview of molecular mechanisms. Inflamm Res 2011;60:409-24.

41. Ghazali WS, Romli AC, Mohamed M. Effects of honey supplementation on inflammatory markers among chronic smokers: a randomized controlled trial. BMC Complement Altern Med 2017;17:175.

42. Petrescu F, Voican SC, Silosi I. Tumor necrosis factor-alpha serum levels in healthy smokers and nonsmokers. Int J Chron Obstruct Pulmon Dis 2010;5:217-22.

43. Mercantepe T, Unal D, Tümkaya L, Yazici ZA. Protective effects of amifostine, curcumin and caffeic acid phenethyl ester against cisplatin-induced testis tissue damage in rats. Exp Ther Med 2018;15:3404-12.

44. Yang WS, Jeong D, Yi YS, Park JG, Seo H, Moh SH, Hong S, Cho JY. IRAK1/4-targeted anti-inflammatory action of caffeic acid. Mediators Inflamm 2013;2013:518183.

45. Hussain T, Tan B, Yin Y, Blachier F, Tossou MC, Rahu N. Oxidative stress and inflammation: what polyphenols can do for us? Oxid Med Cell Longev 2016;2016:7432797.

46. Nemmar A, Al Hemeiri A, Al Hammadi N, Yuvaraju P, Beegam S, Yasin J, Elwasila M, Ali BH, Adeghate E. Early pulmonary events of nose-only water pipe (shisha) smoking exposure in mice. Physiol Rep 2015;3:e12258.

47. Nemmar A, Yuvaraju P, Beegam S, John A, Raza H, Ali BH. Cardiovascular effects of nose-only water-pipe smoking exposure in mice. Am J Physiol Heart Circ Physiol 2013;305:H7406. 